\title{
Achievements and challenges of contemporary energy-efficient architecture in Russia
}

\author{
Fedor Perov ${ }^{1}$, Aleksandra Eremeeva ${ }^{1,{ }^{*}}$, and Salavat Shabiev ${ }^{2}$ \\ ${ }^{1}$ Saint Petersburg State University of Architecture and Civil Engineering, Krasnoarmeiskaya st., 4, \\ 199005, St. Petersburg, Russia \\ ${ }^{2}$ South Ural State University (National Research University), Lenina av., 76, 454080, Chelyabinsk, \\ Russia
}

\begin{abstract}
The growth in demand for the clean habitation environment and the need for the sustainable energy technologies lead to the development of eco-friendly architecture in the world. Eco-friendly design is beginning to play an important role in the design and construction of civil buildings. The article focuses on topical issues of energy-efficient architecture and environmental design in Russia. Statistics show that the energy-efficient construction sector in Russia is developing at a relatively slow rate, and "green architecture" buildings are not wide spread, eco-friendly architecture in Russia is only on the initial stage of the growth. However, the demand for ecological buildings has a positive trend. The article indicates the main reasons impeding the growth of "green architecture" in Russia: state policy and legislation; consumer attitude; or those linked to specific environmental economic prerequisites. The lack of eco-friendly education among the population and, accordingly, the lack of knowledge of Green architecture benefits are also perceived as a problem by the authors. The authors make recommendations to stimulate the development of "green" architecture in Russia and improve the positions of the country on this issue in the global ranking.
\end{abstract}

\section{Introduction}

At the present time, there is a marked increase in acute environmental problems which require urgent solutions. New ways need to be found to optimize the environment for human activity; which comply in the optimum manner with modern requirements. Studies of Alberti, Brust and Cain showed that one of the most effective ways to resolve these problems is to use the potential of eco-friendly or "green" architecture [1, 2, 3]. This most important area of modern architectural science encompasses a range of issues aimed at creating a comfortable environment; saving energy; protecting the environment, as well as other technical aspects related to the optimal choice of building constructs and finishing materials.

"Green" architecture approaches lie at the basis of sustainable development; something in which the entire global community at the present time is interested. "Green" architecture

\footnotetext{
* Corresponding author: arch.eremeeva@gmail.com
} 
is one of the main ways for the efficient use of resources and energy, reduction of waste, limitation of negative environmental impact and enhancement of the conditions for human activity. However, it is important to note that in certain countries the characteristic features of eco-friendly architecture are influenced by climatic features, local traditions and legal regulation.

The objective of the current study was to investigate the peculiarities of eco-friendly architecture in Russia, in order to reveal the achievements and identify the existing problems, which hinder the development of "green" technologies in Russia. The study covers the following issues:

- position of Russia in global ranking in terms of "green architecture";

- constraints on the development of "green architecture" in Russia;

- measures, which can be taken to increase the popularity of "green architecture" in Russia.

\section{Materials and Methods}

\subsection{The place of "green architecture" in Russia in terms of global rankings}

The BREEAM certification program (Building Research Establishment Environmental Assessment Methodology) was developed in the early 1990s in the UK. It became the primary system for assessing buildings for compliance with environmental requirements. This system is currently being used in more than 50 countries worldwide. About 5 thousand buildings around the world have now been certified in accordance with BREEAM requirements (Figure 1).

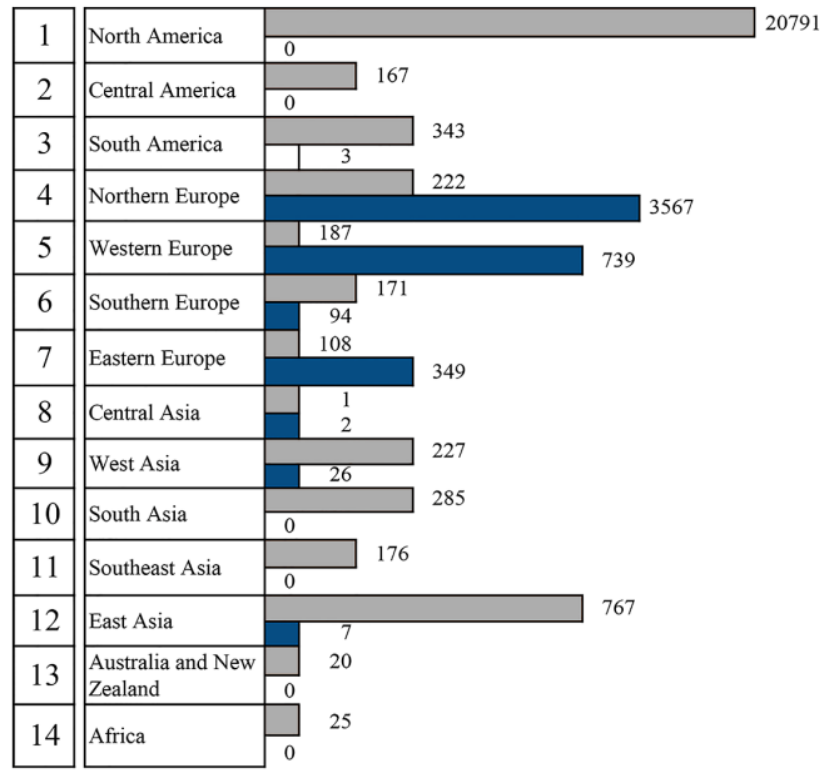

\begin{tabular}{|l|l|}
\hline $\begin{array}{l}\text { The number of projects certified by } \\
\text { LEED (excluding LEED for Homes } \\
\text { projects) }\end{array}$ & \\
\hline $\begin{array}{l}\text { The number of projects certified } \\
\text { according to BREEAM }\end{array}$ & \\
\hline
\end{tabular}

Fig. 1. Global statistics of LEED and BREEAM certified projects for December 2017. 
In 1998 the LEED (Leadership in Energy \& Design) certification program appeared in the USA. The LEED certification system was developed by the Green Building Council [4]. About 23 thousand projects have been evaluated for compliance with LEED standards. Most of these sites, or approximately 21,000, are located in North America [5] (Figure 1).

Russia is lagging far behind the global trend to implement LEED and BREEAM standards. This is due to the relative unpopularity of eco-friendly design solutions in architectural practice, as well as the insufficient development of eco-friendly technologies. Since 2010, the number of projects certified by BREEAM and LEED standards has increased from 2 to 104 in 2017 [6]. About $60 \%$ of all certified buildings are within the office segment (Figure 2), but the proportion of "green offices" in terms of total market volume is still negligible. It accounts for about $3 \%$ of the total supply of office space in Moscow.
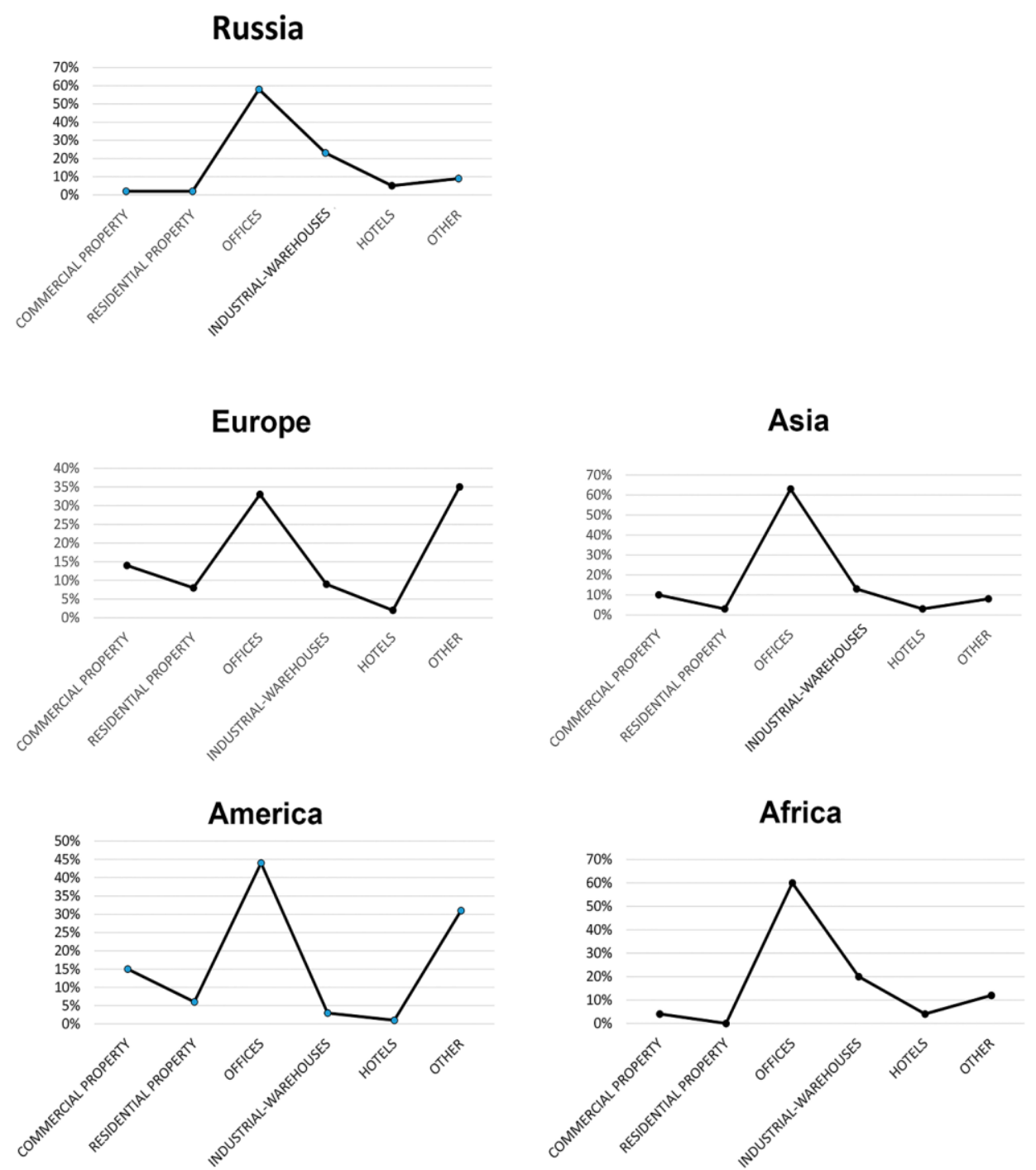

Fig. 2. Number of certified projects in Russia and the world by type of real estate for December 2017. 


\subsection{Problems facing the development of eco-friendly architecture in Russia}

Statistics show that the energy-efficient construction sector in Russia is developing at a relatively slow rate, and "green architecture" buildings are not wide spread. The investigation of the legislation base in eco-friendly architecture and the annual economic reports of eco-friendly construction sphere allowed to determine, that the problems which are holding back the development of "green architecture" are linked to state policy and legislation, consumer mindset or economic prerequisites.

1. The government's position with regard to new energy-efficient standards is ambiguous.

The Russian government is gradually adopting new legislation designed to regulate ecofriendly construction requirements. Nevertheless, significant changes are very slow in coming, since for the most part these documents are advisory or declarative rather than the more stringent legislation of the countries of Western Europe and the USA. The Russian economy has a strong dependence on raw material resources, and the state acts as the main shareholder in most companies in the energy sector. Thus, the paradox of the current situation is that when regulating new energy efficiency standards, the state is not primarily interested in any significant reduction in energy consumption by customers.

2. Russian consumer attitudes.

There are certain particular traits in the attitudes of Russian consumers. Given the accessibility of natural resources in Russia and their relative cheapness, the question of rational energy use is not as acutely felt by the Russian consumer as it is in European countries, for example. This is a factor which is holding back the wider growth of energy efficient construction in Russia [6]. According to public opinion, people are not yet ready for the broad use of energy-saving and nature conserving technologies. Surveys indicate that people do not consider it important or necessary to use renewable energy sources. Even recognizing the need to achieve clean air in the urban environment, only $40 \%$ of respondents were prepared to discuss additional investments in air-purification equipment in residential buildings.

3. Financing and profit.

At the present time, eco-friendly construction for most market participants requires significant initial investments in technology. The resultant $15-20 \%$ price premium reduces commercial attractiveness. The average ROI period for eco-friendly development projects in Russia is somewhere between 8 to 15 years, implying additional implementation risks given the existing uncertainties and volatility of the business sector in Russia [7]. Companies building facilities for their own use or planning to use them over a long period of time support the use of "green" technologies, in the aims of saving heat, electricity, water and reducing other operational costs.

\subsection{Potential for the further development of eco-friendly architecture in Russia}

"Green" architecture in Russia has the potential for future development, notwithstanding the current situation. The efficiency and benefits of using eco-friendly technologies are becoming increasingly evident to the consumer (Figure 3 ). 


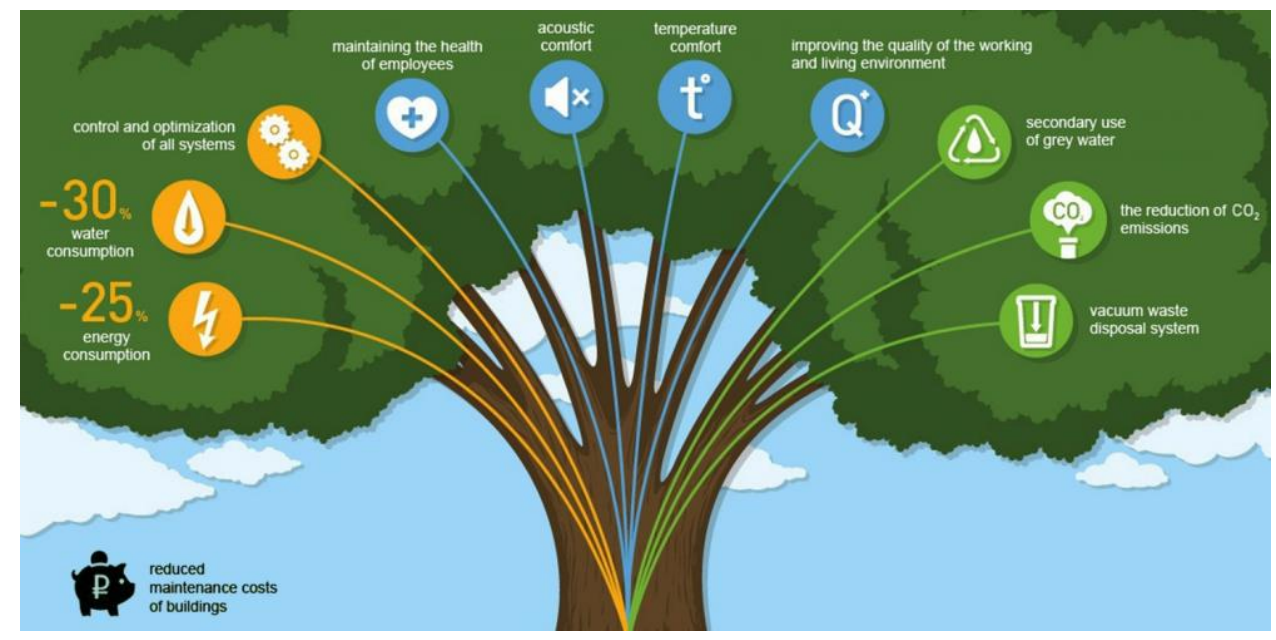

Fig. 3. The advantages of "green" architecture, Source: http://lakhta.center/en/.

In Moscow and the Moscow region, where the real estate market is on the one hand well-developed and, on the other, in terms of its structure close to the markets of the world's major megalopolises, the main drivers of certification are international companies who are interested in leasing energy-efficient and "healthy" rental space [6]. For many international companies with an established social responsibility policy compliance with environmental standards can be a key factor when choosing office space.

In St. Petersburg, there are significantly fewer companies requiring eco-friendly developments. The main factor driving the development of eco-friendly construction in the Northern capital is the initiative of pro-active developers taking the lead. The majority of certified buildings at present are business centres and shopping complexes. In the other regions, the main thrust for eco-friendly development has been sporting events at an international level such as the 2014 Olympics and the 2018 World Cup [6].

RD Construction specialists expect the domestic "green construction" market to grow [7]. Foreign architects, developers, investors working in Russia are contributing elements of foreign environmental standards to the domestic construction industry. There have also emerged a number of domestic companies, as well as specialists and experts, involved in the certification of buildings in accordance with international standards [8]. Confirmation of the growth in demand for eco-friendly building in Russia can be seen in the dynamics of the number of facilities certified over recent years: in 2010 only 2 were certified, while at the end of September 2014, 43 buildings had already obtained certificates, with a total ground area of 2 million square metres. In 2017, the number of certified buildings reached $104[6]$.

\subsection{Measures aimed at stimulating the development of "green" architecture in Russia}

Special measures will be needed to stimulate the development of "green" technologies in Russia. Contemporary construction experience shows that economic interest of developers alone may be insufficient to introduce energy-efficient technologies. In Russia there is no system of financial instruments aimed at stimulating the introduction of energy-saving technologies and measures. The government needs to develop a set of measures to expand the use of "green architecture". These measures may reduce the tax burden for such facilities [9]. 
A regional guideline document entitled "Recommendations for Ensuring Energy Efficiency of Residential and Public Buildings" was adopted in 2012 in St. Petersburg. At the present time, it is mandatory only for buildings being constructed in St. Petersburg with budgetary funds [10]. Only the introduction of mandatory legislation which also affects private investors will allow for the management of modern design solutions based on the requirements of eco-friendly architecture. This will allow for eco-friendly architecture to be effectively implemented in the design documentation in the form of a special architectural and environmental section [11].

A study carried out by "Ernst and Young", the British auditing and consulting company, suggested that one of the main obstacles to the development of eco-friendly architecture in Russia is the lack of knowledge of the benefits of "green" construction. The promotion of "green" construction in Russia is extremely fragmentary in nature. It is something which is discussed by experts within narrow circles, whereas ordinary people do not understand the need for it [7]. Thus, a constant process of environmental education at university level should be developed as part of the curricula of bachelors and masters of architecture, as well as postgraduate students.

\section{Results}

The research confirms that eco-friendly architecture does exist in Russia, but a quantitative comparison with the leading countries reveals a low level of use of "green" technologies in Russian architecture and civil engineering. Examples of eco-friendly architecture are uncommon and generally do not contribute to overall urban development based on the idea of "green" architecture. Nevertheless, there is a positive vector in the development of "green" architecture in Russia and the number of projects certified every year is increasing.

One objective reason for the low prevalence of eco-friendly design solutions in architectural practice in Russia is the absence of strict legislation and economic incentives on the part of the government, the psychological traits of Russian consumers, the insufficient level of teaching the theory of eco-friendly architecture and, as a result, the insufficient application of LEED and BREEAM standards.

Therefore, the authors propose that an eco-friendly architecture for public buildings be developed which will synthesize all the innovative research of both Russian and foreign academics and economists. Based on this methodology, a special curriculum of eco-friendly architecture should be implemented in universities and changes should be made to environmental legislation, in order to encourage the further expansion of "green" technologies in Russia.

\section{Discussion}

The development of eco-friendly architecture in Russia would contribute to the conservation of energy resources of the country. It would meet the needs of current generation of people, without depriving future generations of the same high quality level of living. The cooperation of architects, engineers and government is necessary to ensure that "green" architecture in Russia develops at a high pace. It is also important for the population to understand the positive impact of "green" architecture in order to increase the demand for its construction. Therefore, the authors of the article have identified and attach much importance to eco-friendly education and promotion of "green" architecture. The knowledge about "green" architecture should be familiar not only to specialists, but also to the entire public. 


\section{Conclusion}

The investigation showed that the brake for the development of eco-friendly technologies in Russia lies mostly in the absence of strict legislation and economic incentives for the growth of "green" architecture. But before proceeding to practical actions, it is necessary to simulate the economic effect of possible legislative innovations theoretically, compare costs, their payback period in the process of operation and their eco-friendly impact on the environment.

\section{References}

1. M. Alberti, Advances in Urban Ecology: Integrating Humans and Ecological Processes in Urban Ecosystems (Springer, Washington, 2009)

2. I. Brust, H. Feldmann, O. Uhlmann, Urban Ecology (Springer, Berlin, 1998)

3. M. Cain, W. Bowman, S. Hacker, Ecology (Sinauer Associates, Sunderland, 2008)

4. E. Mordvinova, S. Prohorov, Ecological value of the objects of construction and reconstruction (PGUAS, Penza, 2003)

5. V. Fadeev, K. Agapova, V. Pantjushin, Regional features of green building in Russia (JLL Russia and CIS, Moscow, 2017)

6. T. Mundy, A. Churikov, K. Agapova, G. Guseinova, Market overview of "green" building in Russia. Trends and forecasts (Jones Lang Lasalle Ip, 2017)

7. S. Shabiev, Akademicheskij vestnik UNIIP RAACS 2, 57-59 (2013)

8. L. Egorenkov, Problemy regionalnoj ekologii 4, 95-97 (2012)

9. T. Datciuk, Forecasting of ecological situation in course of building's design, Architecture and Engineering 2, 19-22 (2016) https://doi.org/10.23968/2500-00552016-1-2-19-22

10. P. Mercader-Moyano, Sustainable development and renovation in architecture, urbanism and engineering (Springer, Cham, 2017) https://doi.org/10.1007/978-3-31951442-0

11. R. Northfield, Greening the smart city, Engineering and Technology 11, 5 (2016) https://doi.org/10.1049/et.2016.0503 